O. M. Pihnastyi ${ }^{1}$, Dr. Sc. (Tech.), Assoc. Prof., orcid.org/0000-0002-5424-9843
National Technical University "Kharkiv Polytechnic Institute", Kharkiv, Ukraine, e-mail: pihnastyi@gmail.com

\title{
CONTROL OF THE BELT SPEED AT UNBALANCED LOADING OF THE CONVEYOR
}

Purpose. Development of algorithms for controlling the speed of the conveyor belt, based on the distributed model of the transport system, containing partial differential equations

Methodology. To calculate the parameters of a conveyor line with a variable speed of material motion, an instrument of mathematical physics is used.

Findings. Comparative analysis of conveyor transport system models is performed. Application of partial differential equations for simulating transport systems of conveyor type, which are complex dynamic distributed systems, is substantiated. A non-dimensional model of a conveyor system in instantaneous approximation with the use of partial-derivative equations is presented. A system of characteristic equations is recorded and a solution is developed which defines the value of material flow and material density at an arbitrary point of time for the given point of the transportation route. An expression is obtained which defines the value of material delay in the transport system depending on the velocity defect law for conveyor belt movement. Transition period time is determined during which the output material flow is defined by linear density of material disposition along the transportation route. Dependences for the material linear density and material flow for the steady state condition are defined. The performance criterion of control of flow parameters of the conveyor system is recorded and a solution of the problem of optimal control of conveyor belt speed providing the relay control mode with the minimum power consumption for material movement is found. An example of control algorithm development is given.

Originality. PDE-models of transport systems of conveyor type and energy-saving algorithms for controlling such systems have been improved.

Practical value. The proposed method for calculating the parameters of the conveyor line, which is a dynamic distributed system, can be used to design systems for optimal control of flow parameters of transport systems of conveyor type

Keywords: conveyor, distributed system, PDE-model, production line, belt speed

Introduction. The conveyor is the main way of rock transporting at mining enterprises. Having the length of several dozens of kilometers and carrying capacity of $\sim 10^{4} \mathrm{t} / \mathrm{h}$, the consumed power of conveying transportation system is $\sim 10^{5} \mathrm{~kW}$ [1]. The specific normative power consumption by conveyor transport for moving a ton of rock at a one-kilometer distance is estimated by the range of $(0.1-1.0)(\mathrm{kW} \mathrm{h}) /(\mathrm{t} \mathrm{km})$ : Çöllolar Lignite Open Pit Mine (Turkey, 2010) 0.39 (kW h)/(t km), Coarse ore conveyor system Minera Los Pelambres (Chile) 0.79( $\mathrm{kW} \mathrm{h}) /(\mathrm{t} \mathrm{km})$, Belt conveyor with gearless drive Solution Prosper Haniel Coal Mine (Germany) 0.24(kW h)/(t km) [1], and the total energy consumption for carrying a ton of rock along the entire conveyor line are respectively $\sim 6.8, \sim 10$, $\sim 3.24$ (kW h). The actual energy consumption is much higher due to underload of the conveyor line because of the uneven arrival of rock at the conveyor entry. A sufficient amount of work is devoted to the study of this problem. Among the papers that significantly influenced the development of this scientific direction, one should note the monographs by L. G. Shackmeister, V.G. Dmitriev, S.A. Karimlan. Theoretical and experimental studies of the belt conveyor showed that a decrease in the load factor of the conveyor leads to a hyperbolic increase in energy costs for transportation.

When the load factor is 0.75 , power consumption for transportation increases by $10 \%$, at $0.5-$ by $50 \%$, at 0.25 - by $160 \%$ and at $0.1-$ by $675 \%$ [2]. Such character of dependence causes researchers' considerable practical and theoretical interest to this problem. The offered methods, which allow reducing the actual energy consumption of the conveyor system down to $30 \%$, in most cases, are based on using the accumulating buffer to eliminate the unbalanced conveyor belt load. A mobile (stationary) bunker or the belt conveyor itself serves as an accumulation buffer [3, 4]. The bunker ensures a uniform supply of rock to the conveyor line entry, accumulates excess rock in the accumulator if the rate of receiving is higher than the normative one, or if the rate is lower than the normative one, uses the reserves of rock in the bunker to eliminate the deviation. The speed of the conveyor belt, as a rule, remains

(C) Pihnastyi O. M., 2019 unchanged. Using a bunker in order to stabilize the rate of rock supply onto the conveyor belt required having additional technological space in front of the conveyor line for its placement (Yu. Razumnyi). One more circumstance to consider when designing conveyor systems with an additional bunker is the limited bunker capacity, which requires a control system that does not allow bunker overload [5]. An alternative approach to improving the energy efficiency of conveyor transport is in designing control systems of managing the speed of the conveyor belt. In case of a decrease in the rock flow onto the conveyor belt, the speed is reduced, ensuring a normative linear density of the rock on the conveyor belt, which leads to the accumulation of rock on the conveyor. In case of an increase in the rock flow at the entrance, the speed of the conveyor belt increases, leading to a decrease in the value of the linear density of the rock.

The overview of conveyor line models. The method of increasing the energy efficiency of the conveyor transport by regulating the speed of the conveyor belt is not new (L. Shakhmeyster). However, in spite of the abundance of works, the overview of a small part of which is given below, the issue of improving the energy efficiency of conveyor transport by regulating the speed of the belt is of high relevance today. The conveyor with moving rock along a transport route is a distributed system with a number of restrictions, the most important of which are the restriction in a maximum specific linear load of the conveyor belt and the restriction of the maximum volume of the transported weight (V.Dmitriev). The conveyor system is statistically undetermined. The statistic indetermination lies in indetermination of the volume of the incoming rock flow at the conveyor entry (indetermination of boundary conditions), which requires the use of probabilistic methods in calculating the conveyor line (L. Shakhmeister).

There are a great number of methods for modelling and analyzing the conveyor type transport system. The paper [6] contains the algorithm for conveyor belt speed control, created with the use of theory of mathematical programming. The target function is determined in the work, the necessary conditions for conveyor belt speed control are defined, the simulation model of the conveyor line with the constant speed for 
i-degree regulation and incremental speed control algorithm are presented. The speed for i-degree regulation $a_{j}$ is determined by the expression

$$
a_{j}=\frac{[\chi]_{1 j}}{\psi}=\frac{[\chi]_{1 j}}{[\chi]_{1 n}} a_{n},
$$

where $[\chi]_{1 n}$ and $a_{n}$ are nominal values of the conveyor belt performance speed [6]. Modes of speed control are set from the condition of minimum average belt speed, [6]

$$
\frac{\partial\langle a\rangle}{\partial[\chi]_{1 j}}=0
$$

where

$$
\langle a\rangle=\sum_{j=1}^{N_{s}} a_{j} P_{j} ; \quad \sum_{j=1}^{N_{s}} P_{j}=1 .
$$

The value $P_{j}$ characterizes the proportion of time during which the conveyor line operates with the average speed $a_{j}$.

The statistical analysis of the operating parameters of the belt conveyor is done in [7]. During the modelling, normal and logarithmic normal laws of load flow distribution and the correlation function of mine flow like (V. Dmitriyev), [7] were used

$$
R_{Q}(\tau)=\sigma_{Q}^{2} \exp (-\alpha \tau),
$$

where $\sigma_{Q}(\mathrm{~kg} / \mathrm{sec})$ is the dispersion of a mine load flow; $\alpha$ is the parameter of correlation function. The results of the experimental measurement of the intensity of the incoming flow confirmed the conclusions on the form of the distribution law. The material flow rate reached $533(\mathrm{~kg} / \mathrm{sec})$ with an average value of $134(\mathrm{~kg} / \mathrm{sec})$ and $\sigma_{Q}=66.4(\mathrm{~kg} / \mathrm{sec})$. The amount of material, which is transported, was determined by the expression, $\mathrm{kg}$

$$
M(t)=\int_{t-4}^{t+361} Q(\tau) d \tau
$$

The power spent on the transportation of the material is represented by a regression model [7]

$$
N(t)=N_{x x}+n_{1} M(t),
$$

where $N_{x x}=160(\mathrm{~kW})$ is the power of the non-load running of the conveyor according to the experimental data; $n_{1}=$ $=1.11(\mathrm{~kW} / \mathrm{t})$ is expanding power consumption with the increasing load weight by 1 ton. The experimental value $N_{x x}=$ $=160(\mathrm{~kW})$ is three times as big as the value of capacity of nonload running [14]. The difference is explained by a non-satisfactory state of rollers on the mine conveyor, the friction of the belt on the construction elements, the presence of local resistance to the belt movement at the points of the inflexion of the route profile and other factors (V.Adadurov). The paper [8] presents a model of the container in the form of a dynamic link with the time-dependent transport delay. The volume of the output rock flow from the conveyor belt $[\chi]_{1 \text { out }}$ is determined by the meaning of the input flow $[\chi]_{1 \text { in }}$ and the speed of the conveyor line $a_{i n}$ with the transport delay $T(t)$

$$
\begin{gathered}
{[\chi]_{0 \text { out }}(t)=\frac{[\chi]_{1 \text { in }}(t-T(t))}{a_{\text {in }}(t-T(t))} ;} \\
{[\chi]_{\text {lout }}(t)=\frac{[\chi]_{1 \text { in }}(t-T(t))}{a_{\text {in }}(t-T(t))} a_{\text {in }}(t) .}
\end{gathered}
$$

For the variable conveyor speed, the volume of the transport delay is determined by the numerical method (V. Stavitsky). The weight of rock, distributed along the con- veyor line, is represented by the integral equation $M(t)=$ $=M\left(t_{n}\right) \int_{t_{n}}^{t_{k}}[\chi]_{1 i n}(t) \frac{[\chi]_{1 i n}(t-T(t))}{a_{i n}(t-T(t))} a_{i n}(t) d t$, supplemented with the equation for determining the static tractive force

$$
F=a(M(t)+b) .
$$

Two last equations together form a mathematical model of the belt conveyor as an element of the automatic regulation of the static drive load (V. Stavitsky). For cases when the input cargo flow can be measured, a speed control algorithm with feedback is proposed [8].

The influence of an unbalanced load of the conveyor belt on energy costs for transportation is considered in [2]. Dependence is presented

$$
\begin{gathered}
K_{e}=f\left(K_{z}\right) \approx \frac{1}{2}\left(\frac{1}{K_{z}}+1\right) ; \\
K_{e}=\frac{E\left(M_{i}\right)}{E\left(M_{\max }\right)}: \quad K_{z}=\frac{M_{i}}{M_{\max }},
\end{gathered}
$$

where $M_{\max }$ is the transported weight of cargo on the belt, corresponding to the maximum load of the conveyor by its receiving power; $E\left(M_{\max }\right), E\left(M_{i}\right)$ are energy consumption for transporting one ton $(\mathrm{t})$ of rock at the distance of one kilometer $(\mathrm{km})$ when the conveyor load is $M_{\max }$ and $M_{i}$.

In the paper [9] the mathematical model of the frequencycontrolled electric drive, considering the distributed load of the conveyor line, is developed. A fuzzy regulator of the conveyor belt speed was synthesized. The comparative analysis of transient processes in the electric drive of the conveyor with the fuzzy regulator and without it is done.

The distributed numerical model of belt conveyor dynamics based on finite difference approach is presented in [10]. To perform numerical modelling the conveyor line was divided into $10^{3} \div 10^{4}$ elements, within each of which the equations of dynamics of movement of each section of the conveyor line with rock are solved. The article by Yu. Kozhubayev introduces the linear density of distribution of rock along the conveyor line $[\chi]_{0}(t, S)$ formed by the input cargo flow $[\chi]_{1 \text { in }}(t)$ and the equation defining the meaning of the linear density at the beginning of the conveyor line

$$
[\chi]_{0}(t, 0)=\frac{d m_{\text {in }}(t)}{d t} \frac{1}{a(t)}=\frac{[\chi]_{1 \text { in }}(t)}{a(t)}=\frac{[\chi]_{1}(t, 0)}{a(t)},
$$

where $a(t)$ is the speed of the conveyor belt; $[\chi]_{1 \text { in }}(t)=[\chi]_{1}(t, 0)$ is cargo flow getting onto the conveyor; $S \in\left[0, S_{d}\right]$ is a coordinate characterizing the location on the conveyor belt; $S_{d}$ is the length of the conveyor. The output flow is represented by the expression

$$
[\chi]_{\text {lout }}(t)=[\chi]_{1}\left(t, S_{d}\right)=\frac{d m_{\text {out }}(t)}{d t}=[\chi]_{0}\left(t, S_{d}\right) a(t),
$$

in which the linear density of rock distribution at the input $[\chi]_{0}(t, 0)$ and at the output $[\chi]_{0}\left(t, S_{d}\right)$ of the conveyor line is bound by the correlation

$$
[\chi]_{0}\left(t, S_{d}\right)=[\chi]_{0}(t-\tau(t), 0) ; \quad \int_{t-\tau(t)}^{t} a(\lambda) d \lambda=S_{d},
$$

considering retardation $\tau(t)$. With constant speed of conveyer line movement $a(t)=a_{1}$, we get $\tau(t)=S_{d} / a_{1}$. Based on the latest, an expression is given in the paper for calculating the maximum allowable cargo flow to the conveyor line.

$$
\left([\chi]_{1 \text { out }}\right)_{\max }=\left(\frac{d m_{\text {out }}}{d t}\right)_{\max }=\left([\chi]_{0}(t, S)\right)_{\max } a_{\max },
$$


with a limit to the maximum value of conveyor speed $a_{\max }$ and linear density of distribution of rock along the conveyor line $\left([\chi]_{0}(t, S)\right)_{\max }$.

The article by Diachenko studies the methods for describing the amount of random cargo flow getting onto the conveyor line using empirical distributions. In $[11,12]$ using models of the theory of mass service, the analysis of mine cargo flow, entering the conveyor line is done. In [11] the model of the main trunk conveyor for two input conveyors is developed, the cargo flow of each of them is a random value. In the paper [12] the influence of adjustable drive on cargo flows and energy efficiency of the mine conveyor system are considered. The model of transport system consisting of several successively located conveyors with the speed control of the belt is presented. The choice of the length of conveyors in the proposed model is justified [12]. In paper [13] the dependence of the coefficient of resistance to belt movement on the volume of line load which has a rather complex character is stated. This dependence plays an important role while evaluating the costs of energy spent on transporting the rock by the conveyor with constant and controlled speed, and needs experimental verification under the conditions of working mines.

PDE-model of the conveyor line. The partial differential equations for modeling flow production lines are applied in $[14]$. In works $[15,16]$ the overview of flow lines is given and special attention is paid to models in which partial differential equations are used (PDE models). A new class of models, which received the name PDE models, is meant for describing the production flow lines, functioning in stationary and transient modes. It enables to design the allocation of the subjects of labour along the flow line and considers the stochastic character of interaction the subjects of labour with technological equipment and with each other as a result of technological processing while transferring from one technological operation to another [16].

The conveyor line is a kind of flow line. The peculiarity of constructing the model of a conveyor line is in the fact that the rock placed in different places $S$ on the conveyor line moves with the same speed $a(t)$. It allows presenting the system of equations as

$$
\begin{gathered}
\frac{\partial[\chi]_{0}(t, S)}{\partial t}+a(t) \frac{\partial[\chi]_{0}(t, S)}{\partial S}=\delta(S) \lambda(t) \\
{[\chi]_{1}(t, S)=a(t)[\chi]_{0}(t, S) .}
\end{gathered}
$$

We supplement the system of equations $(1,2)$ with the initial condition

$$
[\chi]_{0}\left(t_{0}, S\right)=H(S) \Psi(S) .
$$

Supposing that it was set at the moment $t_{0}=0$.

Function $\lambda(t)$ sets the load flow at the input of the conveyor the length of which is $S_{d} ; \Psi(S)$ is a linear density of rock allocation along the conveyor belt at the initial time $t=0$, $S \in\left[0, S_{d}\right]$. The system of equations $(1-3)$ determines the model of the conveyor line, which will be used to construct the system of conveyor belt speed control.

We introduce dimensionless parameters and functions

$$
\begin{gathered}
\tau=\frac{t}{T_{d}} ; \quad \xi=\frac{S}{S_{d}} . \\
\psi(\xi)=\frac{\Psi(S)}{\Theta} ; \quad \gamma(\tau)=\lambda(t) \frac{T_{d}}{S_{d} \Theta} ; \quad g(\tau)=a(t) \frac{T_{d}}{S_{d}} . \\
\theta_{0}(\tau, \xi)=\frac{[\chi]_{0}(t, S)}{\Theta} ; \quad \Theta=\max \left\{\Psi(S), \frac{\lambda(t)}{a(t)}\right\} ; \\
\delta(\xi)=S_{d} \delta(S) ; \quad H\left(\xi S_{d}\right)=H(S),
\end{gathered}
$$

where $T_{d}$ is the characteristic average time during which the rock element is being transported.
Taking into account the dimensionless variables and functions (4-6), we can write down equations $(1-3)$ in a dimensionless form

$$
\begin{gathered}
\frac{\partial \theta_{0}(\tau, \xi)}{\partial \tau}+g(\tau) \frac{\partial \theta_{0}(\tau, \xi)}{\partial \xi}=\delta(\xi) \gamma(\tau) \\
\theta_{0}(0, \xi)=H(\xi) \cdot \psi(\xi) .
\end{gathered}
$$

The choice of $\Theta$ makes it possible to provide the scale of meanings of functions $\theta_{0}(\tau, \xi)$. The conveyor lines which have the same type of functions $\gamma(\tau)$ and $g(\tau)$ are similar, have the same behavior when the initial conditions are equal $\psi(\xi)$. This makes it possible to create laboratory analogues for large conveyor lines to conduct practical experiments with them. The results received at the model conveyor lines can be transferred to the operating conveyor lines with sufficient accuracy, which makes it possible to save the means required for conducting experimental research. It remains topical in cases when there is lack of opportunity to conduct experimental research on operating conveyor lines in connection with their load with the production program.

The system of partial difference equations $(7,8)$ corresponds to the system of characteristic equations

$$
\begin{gathered}
\frac{d \xi}{d \tau}=g(\tau) ;\left.\quad \xi\right|_{\tau=0}=\beta . \\
\frac{d \theta_{0}(\tau, \xi)}{d \xi}=\delta(\xi) \cdot \frac{\gamma(\tau)}{g(\tau)} ; \quad \theta_{0}(0, \beta)=H(\beta) \cdot \psi(\beta) .
\end{gathered}
$$

The solution to the equation (9) can be presented in the form

$$
\xi=G(\tau)+C_{1}=G(\tau)-G(0)+\beta ; \quad G(\tau)=\int g(\tau) d \tau,
$$

where the integration constant $C_{1}=\beta-G(0)$ is defined from the condition $\left.\xi\right|_{\tau=0}=\beta$.

Integration of the (10) allows us to write the expression for $\theta_{0}(\tau, \xi)$

$$
\theta_{0}(\tau, \xi)=\int \delta(\xi) \frac{\gamma(\tau)}{g(\tau)} d \xi+C_{2}=H(\xi) \frac{\gamma\left(G^{-1}(G(\tau)-\xi)\right)}{g\left(G^{-1}(G(\tau)-\xi)\right)}+C_{2} .
$$

The constant of integration $C_{2}$ is determined from the (10)

$$
\theta_{0}(0, \beta)=H(\beta) \frac{\gamma\left(G^{-1}(G(0)-\beta)\right)}{g\left(G^{-1}(G(0)-\beta)\right)}+C_{2}=H(\beta) \psi(\beta),
$$

which enables us to write the expression $\theta_{0}(\tau, \xi)$ in the following form

$$
\begin{gathered}
\theta_{0}(\tau, \xi)=H(\xi) \frac{\gamma\left(G^{-1}(G(\tau)-\xi)\right)}{g\left(G^{-1}(G(\tau)-\xi)\right)}- \\
-H(\beta) \frac{\gamma\left(G^{-1}(G(0)-\beta)\right)}{g\left(G^{-1}(G(0)-\beta)\right)}+H(\beta) \psi(\beta) .
\end{gathered}
$$

We express $\beta=\xi-\int_{0} g(z) d z$ from (11), after that we get the solution to the (7) under the initial condition (8)

$$
\begin{aligned}
\theta_{0}(\tau, \xi)= & {\left[H(\xi)-H\left(\xi-\int_{0}^{\tau} g(z) d z\right)\right] \frac{\gamma\left(G^{-1}(G(\tau)-\xi)\right)}{g\left(G^{-1}(G(\tau)-\xi)\right)}+} \\
& \left.\left.+H\left(\xi-\int_{0}^{\tau} g(z) d z\right)\right) \psi\left(\xi-\int_{0}^{\tau} g(z) d z\right)\right) .
\end{aligned}
$$

Equation (12) makes it possible to determine the rock density from the location of the conveyor line, characterized by 
the coordinate $\xi$ for the point in time $\tau$. The resulting solution makes it possible to calculate the non-uniformity of the rock distribution along the conveyor line in a general case. The solution to equation

$$
\xi-\int_{0}^{\tau} g(z) d z=0
$$

sets the law of motion of the point $\xi(\tau)$ along the conveyor belt, on the right of which rock is situated, whose density of distribution is set by initial conditions (9). The total time of the transient mode $T_{d}$, when the initial conditions affect the parameters of the conveyor line, can be received as a result of solving the equation

$$
1=\int_{0}^{T_{d}} g(z) d z
$$

The condition $\tau>T_{d}$ determines the mode of conveyor belt operation, when its parameters do not depend on the initial conditions (8)

$$
\theta_{0}(\tau, \xi)=\frac{\gamma\left(G^{-1}(G(\tau)-\xi)\right)}{g\left(G^{-1}(G(\tau)-\xi)\right)}
$$

If we introduce the denotation

$$
G^{-1}(G(\tau)-1)=\tau-\Delta \tau_{1},
$$

then for the case $\tau>T_{d}$ at the conveyor belt output $\xi=1$ we have

$$
\begin{gathered}
\theta_{0}(\tau, 1)=\frac{\gamma\left(\tau-\Delta \tau_{1}\right)}{g\left(\tau-\Delta \tau_{1}\right)}=\frac{\theta_{1}\left(\tau-\Delta \tau_{1}, 0\right)}{g\left(\tau-\Delta \tau_{1}\right)}=\theta_{0}\left(\tau-\Delta \tau_{1}, 0\right) ; \\
\theta_{1}(\tau, 1)=\frac{\gamma\left(\tau-\Delta \tau_{1}\right)}{g\left(\tau-\Delta \tau_{1}\right)} g(\tau)=\theta_{0}\left(\tau-\Delta \tau_{1}, 0\right) g(\tau) .
\end{gathered}
$$

Assuming that the speed of the conveyor belt is constant $g(\tau)=g_{0}=$ const, the solution to the (13) allows us to determine the interval of the delay in the dimensionless form $T_{d}=1 / g_{0}$. The connection between the input and output flow parameters of the conveyor belt is used for constructing the model of the conveyor line [8]. We also assumed that at the initial point in time, the conveyor line is not loaded $\theta_{0}(0, \xi)=0$ [8]. This leads to the particular case of the initial conditions $\Psi(S)=0$, which determine the conveyor line model in the following form

$$
\theta_{0}(\tau, \xi)=\left[H(\xi)-H\left(\xi-\int_{0}^{\tau} g(z) d z\right)\right] \frac{\gamma\left(G^{-1}(G(\tau)-\xi)\right)}{g\left(G^{-1}(G(\tau)-\xi)\right)} .
$$

The duration of the transitional regime in modelling the operation of the conveyor line was $250(\mathrm{sec})$ with total experiment duration of $2000(\mathrm{sec})$ and control criteria $M(t) \rightarrow M_{\max }$ for time points $\tau>T_{d}=250$ (sec) [8]. The initial conditions for loading the conveyor line $\theta_{0}(0, \xi)=0$ explain the fluctuations in the speed of the conveyor belt and the output flow with a period of fluctuation $T_{d}=250(\mathrm{sec})$. Fluctuation amplitude and period are determined by initial conditions $\theta_{0}(0, \xi)=0$ and criterion of control $M(t) \rightarrow M_{\max }$. Under the initial conditions $\theta_{0}(0, \xi) \neq 0$ the projected control system must lead to fluctuation of general weight of the extracted rock on the conveyor belt. The presence of fluctuations is due to the fact that the expression for flow parameters does not contain the initial conditions. This results in the errors in calculating the modes of conveyor belt speed control and in the work of the system in a non-normative mode, and in case of considerable deviations, in the overload of the electromotors and stopping the conveyor. For a moment in time $\tau<T_{d}$, it is required to set a method for determining the speed of the conveyor belt and the output freight traffic of the transport system. Let us estimate the average duration of the transition period for existing transport systems of the conveyor type [1]:

a) belt conveyor with gearless drive Solution Prosper Haniel Coal Mine (Germany) with the total length of 3800 (m), the average normative speed of line is $5.5(\mathrm{~m} / \mathrm{sec})$, the average duration of transition period is $(\mathrm{sec})$

$$
\Delta \tau_{1}=\frac{3800}{5.5}=690 ;
$$

b) conveyor line for Neyveli Lignite Corporation (India), the total length is $14000(\mathrm{~m})$, the average normative belt speed is $5.4(\mathrm{~m} / \mathrm{sec})$, the average duration of the transition period is $(\mathrm{sec})$

$$
\Delta \tau_{1}=\frac{14000}{5.4}=2590 .
$$

The average duration of the transition period is from a few minutes to an hour. When using the belt speed control systems with the fluctuation range $[0 \div 5](\mathrm{m} / \mathrm{sec})$ the duration of the transition period can be several hours, which can be reflected on the conveyor line efficiency.

The problem of optimal control of the speed of the conveyor belt. The technological consumption of electricity for conveyor transport $W_{k, l}(\mathrm{kWh})$ is determined by the quantity of transported cargo $Q_{p}(\mathrm{t})$, conditions and average running time of the conveyor line $t_{p}(\mathrm{~h})$

$$
W_{k, l}=0.013 L_{k} \cdot w \cdot\left[C \cdot v_{k} \cdot t_{p}+0.28 Q_{p} \cdot\left(1 \pm \frac{\sin \beta}{w}\right)\right],
$$

where $L_{k}(\mathrm{~m})$ is the conveyor length, $w$ is a resistance coefficient (for stationary conveyors $w=0.02 \div 0.03$; for conveyors working at mining extraction areas $w=0.04 \div 0.06$; for conveyors, working under difficult conditions $w=0.08 \div 0.12$ ), $\beta$ (degree angle) is the angle of the conveyor staying, $C(\mathrm{~kg} / \mathrm{m})$ is the linear weight of the carrying parts. The consumed capacity by a stationary conveyor $(w=0.03)$, which is placed horizontally $(\beta=0)$ is determined by the expression

$$
N(t)=\frac{W_{k, l}}{t_{p}}=0.0039 S_{d} \cdot\left[C \cdot a(t)+\frac{1008}{S_{d}} \int_{0}^{S_{d}}[\chi]_{1}(t, S) d S\right],
$$

where length $L_{k}=S_{d}(\mathrm{~m})$, the average speed $v_{k}=a(t)(\mathrm{m} / \mathrm{sec})$ and the average carrying capacity $d Q / d t(\mathrm{t} / \mathrm{h})$ of the conveyor line. The power $N(t)(\mathrm{kW})$ used for transporting rock can be presented as the sum of powers used for $M(t)$

$$
\begin{gathered}
N(t)=0.0039 S_{d} \cdot C \cdot a(t)+0.3931 \cdot a(t) \cdot M(t) \\
M(t)=\int_{0}^{S_{d}}[\chi]_{0}(t, S) d S .
\end{gathered}
$$

Taking into account (14), we can determine theoretical energy consumption, which is necessary for running of the conveyor line $2 \mathrm{LU} 120 \mathrm{~V}$ with the length $S_{d}=730(\mathrm{~m})$, and the average belt speed $a(t)=2.0(\mathrm{~m} / \mathrm{sec})[2,7]: N_{x x}=78.63(\mathrm{~kW}), n_{1}=$ $=0.786(\mathrm{~kW} / \mathrm{t})$.

The conveyor type $2 \mathrm{LU} 120 \mathrm{~V}$, is designed for transporting rock with the normative speed $a(t)=3.15(\mathrm{~m} / \mathrm{sec})$ the maximum capacity $d Q_{p} / d t=1450(\mathrm{t} / \mathrm{h})$ and the weight of the running meter of the moving parts $C=138 .(\mathrm{kg} / \mathrm{m})$

$$
N(t)=123.84+1.23 M(t) .
$$

The calculations used the coefficient of resistance $(w=$ $=0.03)$ and the angle is set $(\beta=0)$. The expression is obtained for a given constant value of the belt speed $a(t)=3.15(\mathrm{~m} / \mathrm{sec})$.

Let us determine the power, consumed by the conveyor which is evenly loaded $\Theta(6)$ along the length of the belt $S_{d}$ and the belt speed $S_{d} / T_{d}(4,5)$ 


$$
N_{\Theta \max }=0.3931 \frac{S_{d}{ }^{2}}{T_{d}} \Theta
$$

we give (14) a dimensionless form

$$
\begin{gathered}
\frac{N(t)}{N_{\Theta \max }}=m_{c} g(t)+m(t) g(t) ; \\
m(t)=\int_{0}^{1} \theta_{0}(\tau, \xi) d \xi=\frac{M(t)}{M_{\max }} ; \quad m_{c}=10^{-3} \frac{C}{\Theta} .
\end{gathered}
$$

For maximum possible transported weight on the conveyor $M_{\max }=126(t) \quad[2]: \quad \Theta=\frac{126}{730}=0.172(\mathrm{t} / \mathrm{m}), \quad m_{c}=$ $=10^{-3} \frac{138}{0.172}=0.79(\mathrm{t} / \mathrm{kg})$. Dividing the left and right parts of the dimensionless ratio for power (15) by the coefficient of rational belt load $m(t)=\frac{M(t)}{M_{\max }}$, we obtain the relation of energy consumption to the unit of weight for actual and nominal load modes

$$
\frac{N(t) / M(t)}{N_{\Theta \max } / M_{\max }}=\frac{m_{c}}{m(t)} g(t)+g(t),
$$

which will be used as a quality criterion for a controlled process. For $g(t)=0.5$ and $m_{c}=0.79$ the optimality criterion is written as

$$
\frac{N(t) / M(t)}{N_{\Theta \max } / M_{\max }}=\frac{0.4}{\int_{0}^{1} \theta_{0}(\tau, \xi) d \xi}+0.5
$$

Using the optimality criterion (16), we formulate the problem of creating an optimal speed control program for the conveyor belt for the established mode of conveyor line operation (12), $\tau>T_{d}$ : to determine the speed control of the conveyor line $u(\tau)$ during the time interval $\tau \in\left[0, \tau_{k}\right]$, which results in the minimum functional

$$
\int_{0}^{\tau_{k}}\left(u(\tau)+u(\tau) m_{c}\left(\int_{0}^{1} \theta_{0}(\tau, \xi) d \xi\right)^{-1}\right) d \tau \rightarrow \min
$$

for differential connections (7)

$$
\frac{\partial \theta_{0}(\tau, \xi)}{\partial \tau}+u(\tau) \frac{\partial \theta_{0}(\tau, \xi)}{\partial \xi}=\delta(\xi) \gamma(\tau),
$$

restrictions for the linear density of the rock on the belt and the maximum possible conveyor drive load

$$
\theta_{0 \max } \geq \theta_{0}(\tau, \xi) \geq 0 ; \quad m(t)=\int_{0}^{1} \theta_{0}(\tau, \xi) d \xi \leq m_{\max },
$$

restrictions of control

$$
g_{\max } \geq u(\tau)=g(\tau),
$$

the initial condition

$$
\theta_{0}(0, \xi)=H(\xi) \psi(\xi) .
$$

Considering the system of characteristic equations $(9,10)$, differential constraints can be represented in the following form

$$
\begin{gathered}
\frac{d \xi}{d \tau}=u(\tau) ;\left.\quad \xi\right|_{\tau=0}=\beta ; \quad \frac{d \theta_{0}(\tau, \xi)}{d \xi}=\delta(\xi) \cdot \frac{\gamma(\tau)}{u(\tau)} \\
\theta_{0}(0, \beta)=H(\beta) \psi(\beta) .
\end{gathered}
$$

The Pontryagin function and the adjoint system for the problem have the following form

$$
H=\psi_{1} u(\tau)-u(\tau)-\frac{u(\tau) m_{c}}{\int_{0}^{1} \theta_{0}(\tau, \xi) d \xi} \rightarrow \max ; \quad \frac{d \psi_{1}}{d t}=\frac{\partial H}{\partial \xi} .
$$

The value of the variable $\Theta_{0 \max }$ determines the maximum possible linear load on the belt.

Since the right end of the phase trajectory is free, then $\psi_{1}\left(\tau_{k}\right)=0$ and, consequently, $\psi_{1}(\tau)=0$, which enables to write down the Pontryagin function in the form

$$
H=-u(\tau)-\frac{u(\tau) m_{c}}{\int_{0}^{1} \theta_{0}(\tau, \xi) d \xi} \rightarrow \max .
$$

The differential constraint (10) makes it possible to express the density of rock distribution along the conveyor line through the input flow and the belt speed for the determined conveyor line mode $\tau>T_{d}$

$$
\theta_{0}(\tau, \xi)=\frac{\gamma\left(G^{-1}(G(\tau)-\xi)\right)}{u\left(G^{-1}(G(\tau)-\xi)\right)} .
$$

Let us consider the construction of the optimal speed control of the conveyor belt for the case when the input flow of the coming rock is constant $\gamma(\tau)=\gamma_{0}=$ const. The weight of the rock on the conveyor belt is defined by the expression

$$
\begin{gathered}
\\
m(t)=\int_{0}^{1} \theta_{0}(\tau, \xi) d \xi=\sum_{j=1}^{N_{s}} \theta_{0}\left(\tau, \xi_{j}\right) \Delta \xi_{j}= \\
=\sum_{j=1}^{N_{s}} \frac{\gamma_{0 \Delta \xi_{j}}}{u\left(G^{-1}\left(G(\tau)-\xi_{j}\right)\right)}=\gamma_{0} \sum_{j=1}^{N_{s}} \Delta \tau_{j}=\gamma_{0} \Delta \tau,
\end{gathered}
$$

where $\Delta \tau$ is determined respectively by the expression

$$
1=\int_{\tau-\Delta \tau}^{\tau} g(z) d z
$$

when $u(\tau)=g(\tau)$ for the value $\xi=1$. The value of the average speed for the period of time $\Delta \tau(\tau)$

$$
u_{m}(\tau)=\frac{1}{\Delta \tau(\tau)} .
$$
pears

When the conveyor line is fully loaded $m(t) \rightarrow m_{\max }$, it ap-

$$
\Delta \tau(\tau) \rightarrow \Delta \tau_{\max } ; \quad \Delta \tau_{\max }=\frac{m_{\max }}{\gamma_{0}}=\frac{1}{u_{\min }} .
$$

When the speed of the belt decreases, the weight of the rock transported by the conveyor and achieving the maximum value, increases. For the condition $\gamma(\tau)=\gamma_{0}=$ const the Pontryagin function will take the form

$$
H=-u(\tau)\left(1+\frac{m_{c}}{\gamma_{0} \Delta \tau}\right)=-u(\tau)\left(1+u_{m}(\tau) \frac{m_{c}}{\gamma_{0}}\right) \rightarrow \max .
$$

For a case $\Delta \tau \ll \tau_{k}$ with a sufficient degree of accuracy, the ratio can be used

$$
H_{m}=\frac{1}{\Delta \tau} \int_{\tau-\Delta \tau}^{\tau} H(z) d z,
$$

what makes it possible to express the Pontryagin function through the average value of the speed of the conveyor line $u_{m}(\tau)$ at the interval $\Delta \tau(\tau)$ 


$$
H_{m}=-u_{m}(\tau)\left(1+u_{m}(\tau) \frac{m_{c}}{\gamma_{0}}\right) \rightarrow \max .
$$

Function $H_{m}$ is decreasing when $u_{m}(\tau)$ is increasing, it has the maximum value when $u_{m}(\tau)=u_{\min }$, which determines the control mode of the conveyor line, fully loaded with rock.

Conclusions and future prospects for the development and improvement of algorithms for controlling the speed of a conveyor belt. To demonstrate the obtained solution, we consider the relay mode of controlling the speed of the conveyor belt $u(\tau)=\left(u_{1}, u_{2}\right)$ for the case of the maximum allowable filling with the conveyor line, determined by condition (17). It should be noted that under production conditions, with the relay law of controlling the speed of the belt, it is required to sustain a pause for damping wavy processes in the conveyor belt. We will assume that the damping time of the arising vibrations is much less than the characteristic time of the process $T_{d}$ and will not affect the final result.

The minimal energy costs per unit of transported products are provided at an average speed of the belt $u_{\min }=\frac{\gamma_{0}}{m_{\max }}$ with the period of relay control $\Delta \tau_{\max }=\frac{m_{\max }}{\gamma_{0}}$. The switching point from the speed $u_{1}$ to the speed $u_{2}$ within the interval $\Delta \tau_{\max }$, is determined from the ratio

$$
u_{1} \Delta \tau_{1}+u_{2} \Delta \tau_{2}=1 ; \quad \Delta \tau_{1}+\Delta \tau_{2}=\Delta \tau_{\max },
$$

consequently

$$
\Delta \tau_{1}=\frac{1-u_{2} \Delta \tau_{\max }}{u_{1}-u_{2}} .
$$

The switching point divides the interval $\Delta \tau_{\max }$ into two intervals $\Delta \tau_{1}$ and $\Delta \tau_{2}$, within which the conveyor line operates with the speeds $u_{1}$ and $u_{2}$ respectively. The amount of interval $\Delta \tau_{\max }$ is determined from the condition of maximum load of the conveyor system.

For the transport system, with the value of the input material flow $\gamma_{0}=0.5$ and the load factor of the transport system $m_{\max }=0.5$ in the case of relay mode controlling the speed of the conveyor belt $u(\tau)=(0.5 ; 1.5)$ we obtain the value of the switching point $\Delta \tau_{1}=0.5$ on the interval $\Delta \tau_{\max }=\frac{m_{\max }}{\gamma_{0}}=1.0$ (Fig. 1). This law of control the speed of the conveyor belt determines the output flow $\theta_{1}(\tau, 1)$ (Fig. 2) and the linear density of the material $\theta_{0}(\tau, 0)$ at the entrance to the conveyor line (Fig. 3). During the transition period $\tau \in\left[0, \tau_{k}=1.0\right]$ the output flow $\theta_{1}(\tau, 1)$ depends on the per unit density of the material distributed over the transport system

$$
\left.\left.\theta_{1}(\tau, 1)=H\left(1-\int_{0}^{\tau} u(z) d z\right)\right) \psi\left(1-\int_{0}^{\tau} u(z) d z\right)\right) u(\tau) .
$$

The initial distribution of the material in a computational experiment is given by the function

$$
\psi(\xi)=\frac{1}{6}+\frac{1}{6} \sin \left(\pi \xi+\frac{\pi}{4}\right) .
$$

When $\tau \geq \tau_{k}=1.0$ the value of the output material flow $\theta_{1}(\tau$, 1 ) is calculated from the relation (18) and with the given data is $\theta_{1}(\tau, 1)=0.5$. The constant value of the output flow $\theta_{1}(\tau, 1)$ for the steady state has a simple explanation. The optimal control algorithm, obtained from a given quality criterion in the absence of a limitation associated with exceeding the maximum value of the material load per belt, ensures a constant value of the material flow in the transport system.

Accordingly, at steady state, the value of the output flow will correspond to the value of the input flow $\theta_{1}(\tau, 1)=\gamma_{0}=0.5$.

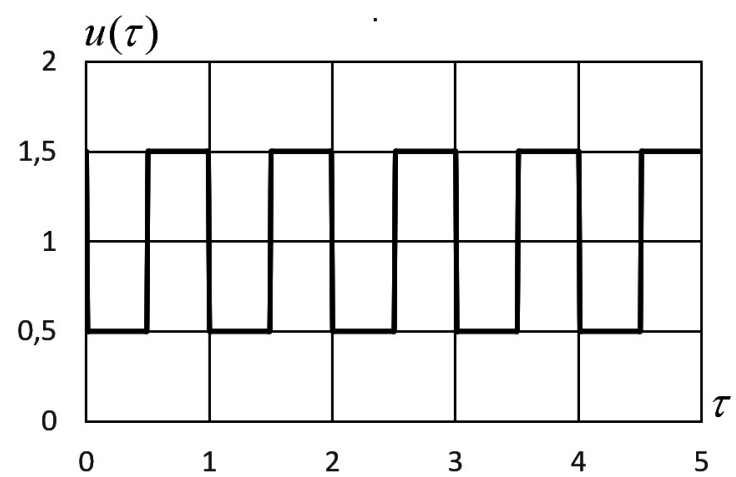

Fig. 1. Relay speed belt control mode $u(\tau)=(0.5 ; 1.5)$

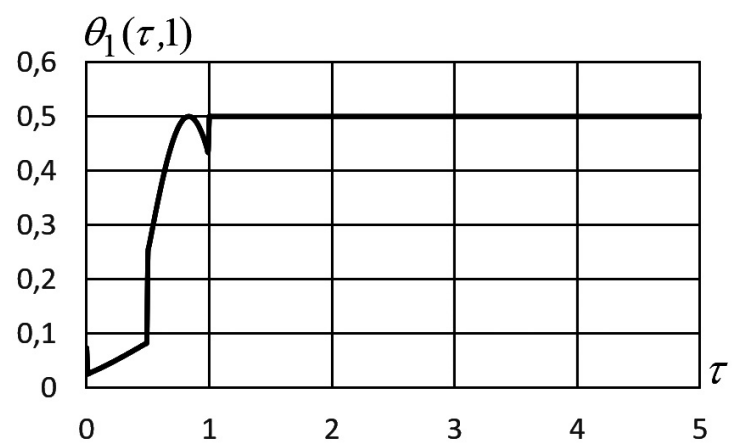

Fig. 2. The output flow from the conveyor line $\theta_{1}(\tau, 1)$, when $\gamma_{0}=0.5, u(\tau)=(0.5 ; 1.5)$

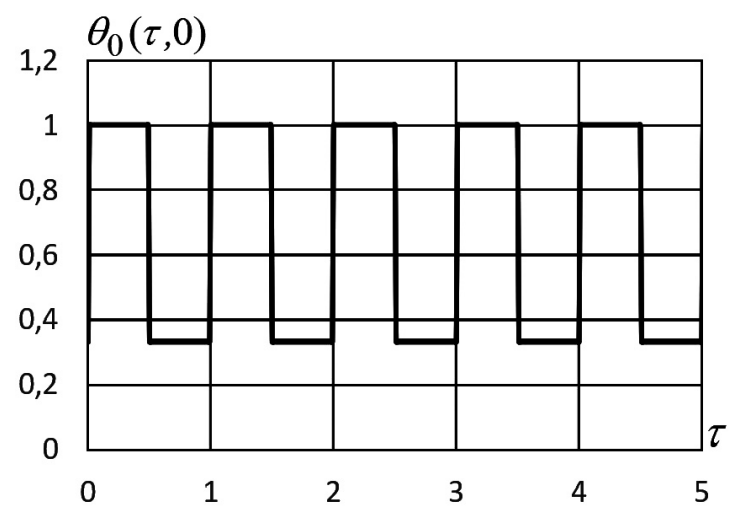

Fig. 3. The per unit density of the material at the input of the conveyor line $\theta_{0}(\tau, 0)$, when $\gamma 0=0.5, u(\tau)=(0.5 ; 1.5)$

The per unit density of the material at the inlet of the conveyor line is shown in Fig.3.

In the general case, for the introduced optimality criterion, the belt speed control is obtained, which, as it is recommended in $[2,7,13,17]$, requires the maximum load of the conveyor line with rock.

With the maximum possible load of the conveyor belt within the time interval $\Delta \tau_{\max }$ energy consumption is constant for speed sets $u(\tau)=\left(u_{1}, u_{2}\right)$, which have the same average value for the belt speed for the period $\Delta \tau_{\max }$. Thus, with the maximum load of the conveyor, energy consumption for the period $\Delta \tau_{\max }$ does not depend on the density of rock distribution along the conveyor line. Minimum energy resources consumption can be ensured by the constant speed of conveyor line $u_{m}(\tau)=u_{\min }$. The law of distribution of linear density of rock along the conveyor line is determined by the given values of speed modes. The change in the law of control leads to the change in the law of distribution of linear density of rock along the conveyor line. The multistage conveyor belt speed control is of interest for the modes of starting and stopping the conveyor when the conveyor belt load is different from the maxi- 
mum value. When constructing the optimal speed control of the conveyor belt, assumption $\gamma(\tau)=\gamma_{0}=$ const is made in the work. At the same time, mine conveyors are characterized by disturbances at the conveyor input, which are expressed by the discrete character of cargo flow and their variable intensity during the period of continuous loading. This is the subject of further research. The simplification supposed in the work is aimed at showing the prospects of using PDE-models when designing highly efficient control systems. Additionally, it was assumed that the incoming freight traffic is a measurable and controllable value. In the case when it is impossible or difficult to estimate the traffic flow, the controlled value can be a static force on the motor shaft.

\section{References.}

1. Siemens (2017). SIMINE for conveyors. Retrieved from https://goo.gl/Ku90xp.

2. Semenchenko, A., Stadnik, M., Belitsky, P., Semenchenko, D., \& Stepanenko, O. (2016). The impact of an uneven loading of a belt conveyor on the loading of drive motors and energy consumption in transportation. Eastern-European Journal of Enterprise Technologies, (82), 42-51. https://doi. org/10.15587/1729-4061.2016.75936.

3. Monastyrskii, V.F., Maksiutenko, V.F., \& Kiriia, R.V. (2010). Efficiency of belt conveyor performance at mining enterprises. Geotehnicheskaia mekhanika, (88), 185-191.

4. Prokuda, V. N., Mishanskii, Yu. A., \& Protsenko, S. N. (2012). Research on and estimation of cargo traffic in linehaul conveyor transport of PSP "Shakhta "Pavlogradskaia" PAO DTEK "Pavlogradugol”. Gornaia elektromehhanika, (88), 107-111.

5. Stavitskii, V. N., \& Ogolobchenko, A. S. (2013). Mathematical modeling of transport system of a production unit. Nauchnyie trudy Donetskogo natsionalnogo tekhnicheskogo universiteta, (1), 53-63. Retrieved from http://science.donntu.edu.ua/ aup/velyada/library/article2.pdf.

6. Reutov, A. A. (2017). Simulation modeling of discontinuous speed variation of the conveyor. Problemy nedroispolzovaniia, (2), 26-32. https://doi.org/10.18454/2313-1586.2017.02.026. 7. Kondrahin, V.P., Stadnik, N. I., \& Belickij, P.V. (2013). Statistical analysis of performance parameters of shaft belt conveyor. Nauchnyie trudy Donetskogo natsionalnogo tekhnicheskogo universiteta, (2), 140-150. Retrieved from http:// nbuv.gov.ua/UJRN/Npdntu_gir_2013_2_15.

8. Stavickii,V. N. (2012). Dynamics of load of variable-speed drive of a belt conveyor. Nauchnyie trudy Donetskogo natsionalnogo tekhnicheskogo universiteta, (23), 49-53. Retrieved from https://goo.gl/UD95Hj.

9. Rebenkov, E.S. (2016). Synthesis of fuzzy regulator of frequency-controlled drive of a conveyor with spring linkage. Mining informational and analytical bulletin, (4), 68-75.

10. Zatonskii, A. V. (2017). Dynamic dimensional model of a multidrive belt conveyor. Vestnik Of Astrakhan State Technical University, (4), 99-110. https://doi.org/10.24143/2072-95022017-4-99-110.

11. Markarian, L.V., \& Selnitsyna, M.V. (2016). Analysis and modelling of occasional mining cargo traffic on linehaul assembly conveyor. Mining informational and analytical bulletin, (5), 67-74. 12. Zaika, V.T., Razumnyi, Yu. T., \& Prokuda, V. N. (2015). Regulated drives influence on coal flow and energy efficiency of mine conveyor transport system. Naukovyi Visnyk Natsionalnoho Hirnychoho Universytetu, (3), 82-88.

13. Lauhoff, H. (2005). Speed Control on Belt Conveyors Does it Really Save Energy? Bulk Solids Handling Publ., (25/6), 368-377.

14. Pihnastyi, O. M. (2015). Analysis of Models of Transient Controlled Production Processes. Scientific Bulletins of the Belgorod State University, (35/1), 133-144. https://doi.org/10.5281/zenodo. 2595561 .

15. Pihnastyi O. M. (2018). Statistical theory of control systems of the flow production. LAP LAMBERT Academic Publishing, ISBN: 978-613-9-95512-1.
16. DIN 22101:2002-08 (2002). Continous conveyors. Belt conveyors for loose bulk materials. Basics for calculation and dimensioning. Normenausschuss Bergbau (FABERG) im Deutsches Institut für Normung. Retrieved from https://www.din.de/en/ wdc-beuth:din21:145598666.

\section{Управління швидкістю руху стрічки при нерівномірному завантаженні конвеєра}

\section{О. М. Пігнастий}

Національний технічний університет „Харківський політехнічний інститут“, м. Харків, Україна, e-mail: pihnastyi@gmail.com

Мета. Розробка алгоритмів керування швидкістю руху конвеєрної стрічки, заснованих на розподіленій моделі транспортної системи, що містить рівняння у приватних похідних.

Методика. Для розрахунку параметрів конвеєрної лінії зі змінною швидкістю руху матеріалу використано апарат математичної фізики.

Результати. Проведено порівняльний аналіз моделей конвеєрних транспортних систем. Обгрунтовано використання рівнянь у приватних похідних для моделювання транспортних систем конвеєрного типу, що є складними динамічними розподіленими системами. Представлена безрозмірна модель конвеєрної системи в одномоментному наближенні з використанням рівнянь у приватних похідних. Записана система характеристичних рівнянь і побудоване рішення, що визначає величину потоку матеріалу та щільність матеріалу в довільний момент часу для заданої точки маршруту транспортування. Отримано вираз, що визначає величину затримки матеріалу у транспортній системі в залежності від закону зміни швидкості руху конвеєрної стрічки. Визначено час перехідного періоду, протягом якого вихідний потік матеріалу визначається лінійною щільністю розміщення матеріалу вздовж транспортного маршруту. Визначені залежності для лінійної щільності матеріалу й потоку матеріалу для сталого режиму. Записано критерій якості управління потоковими параметрами конвеєрної системи та отримане рішення задачі оптимального управління швидкістю конвеєрної стрічки, що забезпечує релейний режим управління за мінімальних питомих витрат електроенергії на переміщення матеріалу. Наведено приклад побудови алгоритму управління.

Наукова новизна. Полягає в удосконаленні PDEмоделей транспортних систем конвеєрного типу та енергозберігаючих алгоритмів управління такими системами.

Практична значимість. Полягає в тому, що запропонований спосіб розрахунку параметрів конвеєрної лінії, який є динамічною розподіленою системою, може бути використаний для проектування систем оптимального управління потоковими параметрами транспортних систем конвеєрного типу.

Ключові слова: конвеєр, розподілена система, PDEмодель, потокова лінія, швидкість стрічки

\section{Управление скоростью движения ленты при неравномерной загрузке конвейера}

\section{О. М. Пигнастый}

Национальный технический университет „Харьковский политехнический институт“, г. Харьков, Украина, e-mail: pihnastyi@gmail.com

Цель. Разработка алгоритмов управления скоростью движения конвейерной ленты, основанных на распреде- 
ленной модели транспортной системы, содержащей уравнения в частных производных.

Методика. Для расчета параметров конвейерной линии с переменной скоростью движения материала использован аппарат математической физики.

Результаты. Проведен сравнительный анализ моделей конвейерных транспортных систем. Обосновано использование уравнений в частных производных для моделирования транспортных систем конвейерного типа, которые являются сложными динамическими распределенными системами. Представлена безразмерная модель конвейерной системы в одномоментном приближении с использованием уравнений в частных производных. Записана система характеристических уравнений и построено решение, определяющее величину потока материала и плотность материала в произвольный момент времени для заданной точки маршрута транспортировки. Получено выражение, определяющее величину задержки материала в транспортной системе в зависимости от закона изменения скорости движения конвейерной ленты. Определено время переходного периода, в течение которого выходной поток материала определяется линейной плотностью размещения материала вдоль транспортного маршрута. Определены за- висимости для линейной плотности материала и потока материала для установившегося режима. Записан критерий качества управления потоковыми параметрами конвейерной системы и получено решение задачи оптимального управления скоростью конвейерной ленты, обеспечивающее релейный режим управления при минимальных удельных затратах электроэнергии на перемещение материала. Приведен пример построения алгоритма управления.

Научная новизна. Заключается в совершенствовании PDE-моделей транспортных систем конвейерного типа и энергосберегающих алгоритмов управления такими системами.

Практическая значимость. Состоит в том, что предложенный метод расчета параметров конвейерной линии, которая представляет собой динамическую распределенную систему, может быть использован для проектирования систем оптимального управления потоковыми параметрами транспортных систем конвейерного типа.

Ключевые слова: конвейер, распределенная система, PDE-модель, поточная линия, скорость ленть

Recommended for publication by L.H. Raskin, Doctor of Technical Sciences. The manuscript was submitted 03.09.18. 